\title{
The return of the political Freud? Some notes on the new historiography of psychoanalysis
}

\author{
- E. Zaretsky, Political Freud: A History, New York: Columbia University Press
}

- M. ffytche and D. Pick (eds), Psychoanalysis in the Age of Totalitarianism, London: Routledge

- D. Herzog, Cold War Freud, Cambridge: Cambridge University Press.

In an illuminating essay on the work of the late historian John Forrester, Andreas Mayer suggested recently that in his early career, 'Forrester set out to solve the problem that must occupy (if not torment) any Freud scholar, namely how to connect the then largely unknown 'Freud 1' (the neurophysiologist) with the very famous 'Freud 2' (the psychoanalyst)' (Mayer, 2017, 155). Mayer, himself a historian of science and a close colleague of Forrester, tells the story of how Forrester managed to bring psychoanalysis back into debates in the history and philosophy of science, after many decades, when historians fully accepted the consensus in the natural sciences that psychoanalysis was not a science. Forrester's project was to find a way of making psychoanalysis a legitimate topic within the history of science on its own terms: namely, without giving up its essential intersubjectivity. Psychoanalysis, he wrote, 'should be a legitimate object for history and philosophy of science - because of the seeming triviality of its objects, because of the fact that it arouses strong emotional responses in scholars and because of the fact that its repeated claims to be recognized as truly scientific have been largely contested'(ibid, 152). However, since the 1970s, at the same time as these debates on how to reconcile Freud 1, the scientist, with Freud 2, the therapist - cultural historians (Forrester included) took a different direction in their research, and attempted to portray a Freud 3 - a 'political Freud'. The three books under consideration here all focus on the history of this 'political Freud', which is also the title of one of them. But who is this 'political Freud'?

\section{Political Freud - an old-new historiography}

Freud was arguably the first historian of psychoanalysis, when as early as 1914 he published 'The History of the Psychoanalytic Movement' (Freud, 1914). Historiography of psychoanalysis, however, has changed dramatically since then, with Freud's own autobiographical studies (1925), through Ernest Jones' seminal biography (Jones, 1953-57) and up until the post-1980s literature, which John Burnham (2006) dubbed the 'New Freud studies'. ${ }^{1}$ However, the works under review here are slightly different from the ones

\footnotetext{
${ }^{1}$ Burnham argues that many of the historiographical shifts of the 1980s onward are the outcome of two main factors: 1) a massive uncovering of some crucial archives; and 2) the taking-over of this field by professional
} 
reviewed by Burnham more than a decade ago. While he refers mainly to scholarship that changed how we understand the early history of the psychoanalytic movement within its central-European context, many recent works focus on Freud's different readers throughout the $20^{\text {th }}$ century, and their very different political agendas. ${ }^{2}$

The 1950s was the formative period, when Freud was portrayed as a man of Enlightenment, the 'godless Jew' - the main historical narrative for many decades. This line of thought became even stronger in the 1970s and 1980s, with works that located Freud as an archetype of the secular 'Jewish renaissance' in fin de siècle Vienna (Rieff, 1959; Schorske, 1973; Gay, 1987; idem, 1988; see also, Ross, 2012). But this perception of Freud was challenged by historians who insisted on writing an 'against-the-grain' history of psychoanalysis, looking not only for what Freud said about himself but also for his 'blind spots'. A new revival of interest in the 'Jewish Freud' since the late 1980s, for example, shifted the way we now see not only Freud himself, but also an entire generation of assimilated Jews in fin de siècle Central Europe (e.g., Gilman, 1993; Yerushalmi, 1991; Slavet, 2009). The 2000s saw another historiographical turn, with the emergence of the '(post) colonial Freud' (Khanna, 2003; Brickman, 2003; Said, 2004; Damousi and Plotkin, 2012). This Freud became, for some scholars, a symbol for the racialization of all the human sciences in the $19^{\text {th }}$ and $20^{\text {th }}$ century, which helped to construct the non-European as the 'primitive' and the ultimate Other. However, the post-colonial turn also revealed the complexity of the Freudian legacy. As some of these scholars have shown, the Freudian project provided us with the hitherto missing theoretical tools to recognize Otherness, specifically racial Otherness. Put differently, the Freudian legacy emerged from a problematic colonial, and very often racial, intellectual history that shaped many of the modern social sciences. Yet it also, paradoxically, provided us with some invaluable epistemological tools in some late 20th century struggles against racism, colonialism, and patriarchal values. In other words, Freud was always political, and reading him is always a reading of a 'political Freud' - the title of Eli Zaretsky's recent book.

Zaretsky's book is one of several other new publications that attempts to provide different answers for the question of what the meaning of such a 'political Freud' might be. The aim of this essay is to review some of the major suggestions that these texts collectively offer. I would also like to propose a shift in historiography from the previous Freud - the post-colonial Freud. These two categories - the 'post-colonial Freud' and the 'political Freud' - are of course not unrelated. However, the latter new historiographical paradigm is now more focused on psychoanalysis as a category of the Western 'self' rather

historians, that replaced, according to Burnham, other 'well-informed and talented writers who were using the history of psychoanalysis as a weapon in their struggles to control the medical, psychological, and philosophical understandings of Freud and the Freudians'[(214]).

\footnotetext{
${ }^{2}$ Nevertheless, some major new contributions are still to be considered as part of the 'New Freud Studies' in Burnham's sense, let alone some new biographies of Freud (Roudinesco, 2016; Whitebook, 2017). For example, many years after the futile debates of the 1980s on whether Freud was a 'pseudo-scientist' ('biologist of the mind') or not, Guenther (2015) and Mayer (2013) provided us with two different sophisticated and important studies about the neurological origins of psychoanalysis in the prepsychoanalytic period of Freud.
} 
than on providing critical accounts of how psychoanalysis demonstrated Western projections of the non-Western Other.

But first, why 'Political Freud'? And why not the 'political' Ferenczi, Jung, Lacan, Klein, Winnicott, Kohut - or indeed 'political psychoanalysis'? After all, a major achievement of the last three decades in the historiography of psychoanalysis has been the way in which this scholarship demonstrates how Freud was far from the only important figure in psychoanalytic history, and that the history of psychoanalysis is much bigger than psychoanalysis itself. That is, historians have repeatedly shown that the history of psychoanalysis is part and parcel of 20th century history, and that this is the right context in which to study the field - together with the Bolshevik revolution, the emergence of European fascism, the Cold War, the European Union, the fall of Berlin Wall, and the rise of neoliberalism. Moreover, scholars such as Zaretsky were eminent figures in a long struggle during the past few decades to open the gates of history more widely to psychoanalysis - as well as to make way for the study of key figures within the history of psychoanalysis beyond Freud himself. Why, then, is there a 'return to Freud'? And why now?

First, it should be said that although some of the recent works certainly show a 'return to Freud', they also use Freud as a signifier for psychoanalysis in the political and cultural realm, rather than taking Freud-the-man as the one and only father of the psychoanalytic movement. Furthermore, the new paradigm of a 'political Freud' emerged (and is still emerging) at the same time as other historians emphasized the eclectic character of psychoanalysis within the wider history of $20^{\text {th }}$ century 'psy-disciplines' (Rose, 1998). The primary questions for contemporary historians of psychoanalysis such as Shapira (2013), Robcis (2013), Forrester and Camron (2017) and El Shakry (2017) are: who is the Freud about whom we are talking in each case? What was his role in a specific network of a specific 'psy' community? What was the role of this 'psy' community in a wider historical context? Thus, if a 'return to Freud' takes place in the recent historiography of the 'psy' disciplines, it is a very different Freud from the one who has occupied the literature until very recently.

\section{Return to the political Freud}

Zaretsky's book is neither a political biography of Freud (which can be found in numerous other places, including in Zaretsky's seminal book, The Secrets of the Soul; see also Whitebook, 2017), nor is it necessarily a guide for Freud's political worldview. Rather, the book provides several genealogies of how Freudianism was used as an inspiration for 'progressive' politics in some of its most important subjects - and turning points - in 20th century history, and especially in American history (e.g., black history, antisemitism, the feminist movement). As such, Zaretsky's aim is to explore the radical promise of political Freudianism - a promise that typically was not fulfilled. His case studies '[highlight] two seemingly antithetical moments: a critical moment when political thinkers and social movements looked to psychoanalysis to clarify the irrational sources of domination; and an affirmative moment when Freudianism became submerged in a larger history and appeared to become obsolete'(12).

Thus, for example, the second chapter tells the story of how Freud was admired by a number of leading black thinkers and artists, from the interwar Harlem Renaissance, through the Popular Front and Marxo-Freudianism, and up until the highly influential postWWII 'Freud of the Black Atlantic' best represented by Frantz Fanon. For black intellectuals 
and activists, Freud was always political, because the personal, cultural and historical trajectories of those figures who used Freudianism for their political struggle were incapable of suggesting otherwise. They did not have the privileges that white middle class psychoanalysts and scholars had-that is, the privilege of insisting on a non-politicalFreud. For white middle class consumers of psychoanalysis, a non-political Freud was crucial for the emergence of 'personal experience or introspection'(28), a major feature of the second industrial revolution:

For middle class white America, psychoanalysis served as avatar, interpreter, and authority over private, intimate space. In African American society the line between public and private was more tenuous, breached by racial intimidation, economic victimization, and sexual misuse (40).

Thus, 1920s Freudianism was not only a crucial discourse for the construction of 'African American memory' but was also an important discourse in the black media, where one could find articles such as 'The psychoanalysis of the Ku Klux Klan' and 'The Mirrors of Harlem: Psychoanalyzing New York's Colored First Citizens'(45). In 1939, the pioneering African American author Zora Neale Hurston published her novel, Moses, Man of the Mountain, which was inspired by Freud's Moses and Monotheism. Other African American authors used Freudian ideas to explore topics such as domesticity, sexuality, femininity and masculinity within their racist political reality. For an author such as Ralph Ellison there was no need to turn Marx into a Freudian, or Freud into a Marxist - they were two sides of the same coin. Late 20th century commentators convincingly portrayed Freud as a Eurocentric thinker, which he probably was. But for someone like Fanon it was actually 'the anticolonial Freud' who helped him to create his huge political legacy. It was this 'anticolonial Freud' who provided him with a better language for describing the racial unconscious governing the colonial world And yet, Zaretsky points to the fact that it was only after many of the great prophets of the Black revolution such as Wright, Fanon, and W. E. B. Du Bois died in the early 1960s that 'the activist movements were born' (77). In other words, when the Civil Rights movement arrived, Freudianism was no longer part of its vanguard. For Zaretsky, a 'political Freud' is always a sort of Moses who can see the Promised Land but is never allowed to enter it.

Freud's Moses stands also at the centre of chapter three. In his highly-acclaimed book, Freud's Moses, Yosef Hayim Yerushalmi (1991) suggested a new and provocative interpretation of Freud's famous book about the biblical Moses. One of his main interventions was to reclaim the old anti-Semitic accusation - to which Freud was particularly sensitive - that psychoanalysis is a Jewish Science. Indeed, against Freud's explicit intention, he suggested that whether we like it or not, 'history made psychoanalysis a "Jewish science"' (98), and that should no longer be a cause for shame. While Yerushalmi and others emphasized the particularity of the Jewish history in early psychoanalysis, it was Edward Said (2003) who presented a different view of the Mosaic legacy of Freud by reading Moses and Monotheism as an Ur-text of post-colonial studies. In his reading of Freud's Moses, Zaretsky refuses to take sides between Yerushalmi and Said, namely between reading Moses and Monotheism as a Jewish book and the post-colonial reading of it. However, he reminds us of an almost forgotten truth: Moses and Monotheism, written between the 1934 and 1938 and published only in 1939 when Freud was already in London, is 'a work of Jewish testimony, written by a political refugee' (110). Zaretsky 
suggests locating it alongside other 'works by exiles such as Erich Auerbach and Hannah Arendt and survivors Primo Levi and Paul Celan'(108). Reading Zaretsky's two chapters together, one might think of adding another political refugee to this list: Frantz Fanon. Indeed, for Zaretsky the history of psychoanalysis and the history of the $20^{\text {th }}$ century refugee are part of the same chapter.

There is something misleading in Zaretsky's full title, Political Freud: A History, which contains the promise of a much fuller historical account, geographically and chronologically. The book is mainly focused on case studies taken from Anglo-American history (e.g. Freudian thinking on race; WWI, WWII and the invasion of Iraq; New Left and the feminist movement in 1960s and 1970s- all very focus on the American scene), which makes one wonder about the absence of the Latin American 'political Freud', the Zionist 'political Freud'3 - indeed, the absence of the European 'political Freud' in the postFreudian Period? 4

Yet it is a timely book, as it designates a 'return to Freud' - not the Lacanian 'return to Freud' of the post-WWII era, but rather the return to a 'political Freud', at a time when such a Freud is much-needed. It is not by chance that a few months after the book was published, and a few months before Trump was elected, Zaretsky published an online article on 'American Id: Freud on Trump', in which he asked: 'Is it possible to read Freud historically in a way that can illuminate the Trump phenomenon?' (Zaretsky, 2016). In other words, Zaretsky provides us with some historical case-studies for what psychoanalysis as a political category might be, and then offers - sometimes controversially - ways to understand the history of psychoanalysis as the history of our present political reality. Political Freud suggests that a major aim of historians of psychoanalysis is to trace back Freud's readers, or even people who might have read him. These readers, or potential readers, should be contextualized if we wish to have a better understanding of their political motivations and the social dilemmas that made psychoanalysis so suggestive for them - indeed, what took place outside the psychoanalytic library to draw them into it. The emergence of neoliberalism, neuroscience, and identity politics in the late $20^{\text {th }}$ century, Zaretsky argues in the Afterword, made psychoanalysis seem somehow 'obsolete'. But for many decades, it helped, for example, 'Black radicals think through the long-term effects of slavery and racism', or 'characterize World War II in a way that illuminated the special role played by anti-Semitism' (196). It was Freud's readers -in 1920s Harlem, in 1970s feminist circles in London, and in post-9/11 America who turned him into a political figure, namely a signifier for the possibility of a radical social change, even if ultimately this was more often than not an unfulfilled promise. We live in an age where these readers are becoming fewer and fewer, summarizes Zaretsky, and so this political Freud becomes increasingly less relevant.

\section{Psychoanalysis between the totalitarian 'there' and the liberal 'here'}

\footnotetext{
${ }^{3}$ Some of these histories can be found in other places. See, Demasio and Plotkin, 2012; Rolnik, 2012; Liebscher, 2017; and Herzog (2016) that will be discussed shortly.

${ }^{4}$ In a discussion with John Forrester, published in ffytche and Pick (2016), Zaretsky replied to some of his critics, who claimed that he was focusing too much on the American perspective in his earlier book, Secrets of the Soul. While accepting part of their criticisms, he also accused them- and not unconvincingly - of using the same coin albeit the other way around: his focus on American history is to some extent a reverse mirror to other psychoanalytic scholars' Eurocentrism.
} 
Psychoanalysis in the Age of Totalitarianism provides a different model of a 'political Freud', by studying a very specific historical period, namely between 1933 and 1963 (when J.F. Kennedy was murdered). This was the era of the paradigmatic $20^{\text {th }}$ century totalitarian regimes, Nazism and Stalinism; but it was also the golden age of the psychoanalytic cause. Indeed, in the age of totalitarianism, psychoanalysis was all around, either as an idealized treatment model and way of thinking, or a target of persecution - and sometimes both. Totalitarian regimes persecuted psychoanalysis as a 'Jewish science' in Germany, and as a 'bourgeoisie psychology' in large parts of the Soviet Bloc (although it never totally disappeared in communist states, as old historiography used to claim). In some cases, however, dark regimes used psychoanalytic movements and even psychoanalysts themselves as a façade of a plural society, or even as a source of information for intelligence agencies against suspected 'dissidents'. ${ }^{5}$ In these cases, it is the history of Latin American psychoanalysis after WWII that immediately comes to mind (even if the relevant case studies often occurred later than 1933-1963). As John Forrester, to whom this volume is dedicated, aptly put it in his discussion with Eli Zaretsky: 'the difficulty about South America is that it might be a very uncomfortable truth for psychoanalysts to recognize that it can survive under some circumstances if the liberal professions are protected (138)". Perhaps the most intriguing and widely unknown example of the appalling connections between psychoanalysis and the liberal state is the collaboration of senior psychoanalysts and the CIA (and other related North American intelligence agencies) for producing political propaganda, mind-control, brainwashing, and indeed all sorts of torture in the Cold War era - as Knuth Muller describes in his contribution to the book. This troubling genealogy -from American ego-psychology to Abu Ghraib - should disturb all those concerned with keeping clinical psychology in general, and psychoanalysis in particular, safe from becoming the tools of political crimes.

As I mentioned earlier, since the 1990s post-colonial scholars have been making a major critique of the abusive political usage to which psychoanalysis can be put. Although colonialism is not a major theme in Psychoanalysis in the Age of Totalitarianism, the two essays that deal directly with the topic suggest fresh and original perspectives to recent historiography, precisely on this issue of universalism. Some of the chapters show how the history of psychoanalysis challenges the idea that universalism and emancipation of colonialism are always contradictory. Indeed, the universalistic dimension of Freudian psychoanalysis was very appealing in post-war thinking about de-colonization. In their chapter, Ross Truscott and Derek Hook problematize this picture by showing how for figures such as the South African psychoanalyst Wulf Sachs and the psychologist Chabani Manganyi, psychoanalysis as a universalist paradigm served as an intellectual resource for developing an effective resistance to the apartheid regime. In a segregated society such as South Africa, the idea of universalistic psychology, which can be applied to everyone, regardless of race, could be attractive to many. Thus, Truscott and Hook argue that 'in disputing the validity of different racial categories in relation to the function of the Oedipus complex and melancholia, Sachs went against the grain of accepted psychoanalytic wisdom

\footnotetext{
5 On the history of psychoanalysis under authoritarian regimes in Latin America see, for example, Dagfal, 2012; Russo, 2012; and the more personal foreword of Catalina Bronstein to Psychoanalysis in the Age of Totalitarianism. See also below the discussion on Derrida (1991), which is still one of the sharpest texts on the need to politicize Freud.
} 
even while using psychoanalytic thinking to do so' (197). After several decades of postcolonial studies, we are now more familiar with historical narratives of how psychoanalysis was so useful in colonizing people's minds, but Truscott and Hook uncover a different aspect of the story. Namely, how a political reading of Freud provided agency and voice to individuals to whom such voice was denied on a purely racial basis. We might find it hard today to imagine why universalism was so appealing for some black and non-black patients, therapists and scholars in a segregated society like South African in the apartheid days, but perhaps this can tell us more about our own society, as well as our own inability to imagine different times and places where identity politics played only a negative role in reconstructing people's 'selfhood' (see also Bertoldi, 1998).

Literature about psychoanalysis and colonialism is often identified with Franz Fanon, who was a major inspiration for contemporary post-colonial scholars. ${ }^{6}$ Erik Linstrum, however, opens his chapter on psychoanalysis in the age of decolonization, with a discussion of Fanon's rival, Octave Mannoni - a French psychoanalyst who spent two decades in Madagascar, and published the then widely read book Prospero and Caliban (1956). Mannoni was notorious for arguing that colonialism created 'a pathological relationship of mutual exploitation', or what he described as 'dependency complex' (182). Colonized people, he claimed, do not know any other model apart from being governed by colonialists according to a parental model, in which they play the role of children. Likewise, however, Mannoni predicted the huge difficulty experienced by European people in the post-colonial age in adjusting to a new world where formerly colonized peoples no longer had to be obedient to them. As Linstrum demonstrates, Mannoni's views reflected a much wider common opinion in Britain, where psychoanalysis helped commentators to articulate feelings of anger, mourning, and regret for their diminished power to rule. Some psychologists warned against a 'pathologization' of the post-colonized societies in Africa and India, as the latter suffer - and will suffer even more in the future, so was the claim from problems such as 'inferiority complex', 'wounded self-esteem', and 'aggressive attitudes' (187). Many described people in formerly-colonized societies in terms of a nonmature 'child's desire to be equal to his elders' (ibid), to use the words of Alix Strachey. For others, ex-officials, Mannoni helped to acknowledge their part in operating racial colonial regimes, and in some cases, even to express regret. In the age of de-colonization, 'the familiar model of the official as father figure was increasingly overlaid with another template: the official as psychoanalyst' (191). Some scholars are now turning back to assess how colonial psychology influenced political discourses of the colonizers back home, in Europe, rather than in the colonies themselves. Whether or not Truscott, Hook, and Linstrum designate a wider new revisionist approach to post-colonial historiography is yet to be seen, but surely these two contributions bring a much-needed fresh and original perspective to some established debates.

Alongside this history of abusing psychoanalysis for the purposes of governing totalitarian states or colonizing non-European societies, there is a different intellectual history in which psychoanalytic thought claims to have a distinctive understanding of the

\footnotetext{
${ }^{6}$ One may recognize another historiographical shift within Fanon studies, where scholars gives much more attention to the influence on, as well as the importance of, Fanon in the mid-20 $0^{\text {th }}$ century negritude movement (rather than the focus hitherto on Fanon in the philosophical context of French existentialism). See Gordon, 2015.
} 
totalitarian state of mind due to its ongoing encounter with the ways in which the 'political' meets the individual unconscious. In other words, for the psychoanalyst, there is something about the clinical realm itself (i.e., the imagined or real intervention of the analyst in her patient's life) that gives her some specific knowledge of the mind under totalitarian rule. The British psychoanalyst Nick Temple describes a case study in which one of his patients 'experienced him as a "bullying, cruel, dictatorial figure who was forcing dogmatic views onto her"' (p. 17). The fact that it was 'here', in the liberal West, that this patient experienced psychoanalytic treatment as totalitarian is particularly instructive, because it is mainly 'here' rather than 'there' (e.g., Nazi Germany, communist Russia, China), that 'the two-way traffic between ideas of psychoanalysis and totalitarianism' (12) played such a central role. Thus, this volume tells us a great deal about liberalism and liberal societies more than it explores new realities for societies under totalitarian regimes. As Joel Isaac puts it in his introductory chapter on the controversial history of totalitarianism , 'by describing the history of psychoanalysis in the age of totalitarianism we are describing the connections between psychoanalysis and the emergence of a certain kind of qualitative or existential politics, rather than merely procedural or legalistic liberal politics' (24). Furthermore, Peter Mandler argues that at its worst, psychoanalytic vocabulary served liberal societies as 'universal yardstick of 'normal' mental health that produced a rich language of reassurance for 'healthy' allies and an even richer language of pathology with which to stigmatize 'sick' enemies' (102). Even when it was not used in forms that could be considered by us today as propaganda, psychoanalysis was used as an ideological tool against totalitarian enemies, and was therefore part of the 'age of totalitarianism' (a careful choice of words by the editors, Matt ffytche and Daniel Pick). This is particularly evident in the case of the postwar British School of Psychoanalysis - as Michal Shapira and Sally Alexander show in their illuminating chapters - which fully endorsed the new welfare state as a necessary framework for the making of democratic minds; at the same time, the implementation of psychoanalytic ways of thinking were perceived as a necessary precondition for maintaining a long-lived social democratic society.

Even for some of the most vocal critics of the liberal state, such as Adorno and Horkheimer, the anxiety about a totalitarian future and their own forced exile brought them, by the 1950s, to mourn the decline of the paternal role in traditional society, as Freud portrayed it. ${ }^{7}$ As ffytche shows, this was the same paternal role that they regarded in the 1930s as the foundation of bourgeois society, which must be radically removed for any Marxist revolution to emerge. Here again, totalitarianism was a concept discussed 'here', in the West, to describe what happened or has been happening 'there', even when it was used by scholars who arrived from 'there'. Thus, usage of the term 'totalitarianism' cannot in

\footnotetext{
${ }^{7}$ See also Stephen Frosh's chapter on Studies in Prejudice (1950) written by the Frankfurt School scholars, Max Horkheimer and Samuel Flowerman. Frosh shows how much of their effort to provide an explanation of antisemitism just after the Holocaust was imbued with colonial language about the fall of 'civilised' society to a form of 'atavism', rather than part and parcel of modernity itself, as Zygmunt Bauman suggested many decades later (Bauman, 1989). Frankfurt School thinkers also tend to explain antisemitism in Marxist terms as one form of racism in the modern age, namely that the figure of the 'Jew' was part the structure of capitalism, where he or she played the role of the 'Other'. But if 'otherness' is only a role that could be played by different discriminated people 'then why are the Jews so consistently chosen as the recipients of this particular form of racialized violence'? (37).
} 
itself provide us any knowledge of the historical reality of so-called 'totalitarian' societies. In the words of Michael Rustin,

'Totalitarianism' like other social phenomena is not merely a 'fact in itself', or indeed a memory of such facts of the past, but is itself also a 'social construction.' The idea of totalitarianism was plainly value-oriented, since totalitarianism as a category lies at one end of an ideological spectrum, at the other end of which lie liberalism and pluralism as opposed principles of social organization (222).

In other words, the term 'totalitarianism' was ideologically loaded, intended to designate foes and friends in post-war America and Western Europe.

It should be noted that Rustin is the only scholar in this volume to mention Friedrich and Brzezinski's then famous and now neglected book, Totalitarian Dictatorship and Autocracy (1956), in which the two provided a typology of the six basic features of a totalitarian society. Their text was a seminal to a whole generation of Cold War political scientists, and for long time as important as Arendt's Origins of Totalitarianism, if not more influential. While Arendt became one of the great heroines of the global left in the last few decades for what were perceived to be her prophetical theses, and while her texts proved as relevant to a neoliberal and allegedly post-ideological society, Friedrich and Brzezinski's work is a real testimony of the fact that totalitarianism cannot be treated as a neutral category.

Ana Antic's study of the role of 'psy' disciplines in the 're-education' of political prisoners in Cold War Yugoslavia, is the only chapter in the book to research the historical reality 'there', in the East, in places under so-called totalitarian regimes - in contrast to a totalitarianism as an analytical construct of Westerner thinkers. Antic's research is pioneering in showing the reliance of an arguably 'totalitarian state' on these very notions of the 'psy' sciences when conducting 're-education' of political dissidents (which was not as she convincingly shows in this and other publications - simply a form of torture in the eyes of its practitioners). However, her insistence that it was the psychoanalytic discourse which set the tone, rather than eclectic methods taken from other, different psychological schools and tailored specifically to the Yugoslavian project, remains only partially substantiated.

Totalitarian society, Hannah Arendt argued, is a society in a denial; that is, denial becomes a form of survival. 8 The refugee escapes not only a brutal reality but also an injunction not to know his or her own reality in order to stay alive. If, for Freud, life was an ongoing negotiation between the reality and pleasure principles, then under such circumstances of denial of reality, does the 'reality principle' have any meaning at all? Can any political resistance be achieved when the idea of 'truth' itself is so deeply under attack? Lyndsey Stonebridge provides some answers to these questions by reading Arendt - a lifelong opponent of psychoanalysis - together with Anna Freud. ${ }^{9}$ Both women were not only refugees themselves but had deep interest in the psychical reluctance of persecutors and persecuted human beings to come to terms with reality. Furthermore, for both 'we are

\footnotetext{
${ }^{8}$ On 'denial' in history see Hall and Pick (2017), which is an introduction to a special issue of History Workshop Journal on the subject.

${ }^{9}$ See, however, Jacqueline Rose's chapter on some surprising psychoanalytical dimensions in Arendt's thought.
} 
obligated to reality precisely because we are not the only person in the world' (53); that is, both were motivated in their quest for reality by an ethical crisis no less than by psychological interest. For Arendt, this feeling that one is the only person in the world is the gist of the totalitarian state. According to her, then, the outcome of the totalitarian world is a psychological state belonging to the individual. However, her recognition of a political reality with a unique psychological state of mind says something about her as an observer, and not only about her observed subjects. Bringing 'totalitarianism' into the $20^{\text {th }}$ century political dictionary seems now to be a moral project no less - and perhaps even more - than an historical attempt to explain what really happened 'there'. In this case too, Arendt and Anna Freud illustrate the postwar liberal societies in which they lived and worked for many decades after WWII, perhaps more than they describe what a totalitarian state was as a historical reality for its citizens.

If totalitarianism - like psychoanalysis - is so deeply rooted in psycho-social and psycho-political mental phenomena, one might ask how useful it is as an analytical tool for historians. Is it useful to better understand what really happened in Auschwitz, or the Soviet Gulag, or for that matter, Guantanamo Bay? Indeed, perhaps it would be a mistake to simplistically compare 20th-century concentration camps to post-9/11's crimes in the 'war on terror'. As Ruth Leys aptly claims in the final chapter of this important volume, there is good evidence to suggest that we not only live in a 'post-psychoanalytic' world, but also in a 'post-totalitarian' one. Both right and left, she argues, keep portraying the $20^{\text {th }}$ century concentration camp as the main threat to humanity (hence, Leys is one of the fiercest critics of Giorgio Agamben), while in fact, focusing on these earlier models of authoritarianism and fascism serves all too well to avoid any confrontation with neo-liberal crimes, which are different in their essence and yet keep producing new historical forms of authoritarian regimes. By treating totalitarianism as the most fundamental threat to modernity, 'both the left and the right can ignore the very real contemporary problem of economic poverty resulting from global capitalism' (245), she claims. I agree with Leys that even if we should historicize the age of totalitarianism, and even if we are able to reflect on some similarities and continuities between that era and our own, we should always bear in mind that 'totalitarianism' is not necessarily useful for understanding the neo-liberal crisis and its catastrophic outcomes - including the environmental crisis, the refugee crisis, and the ongoing strengthening of nationalistic right-wing movements all over the world. 10

\section{Political Freud: the return to Europe}

In Cold War Freud, Dagmar Herzog (also a contributor to Psychoanalysis in the Age of Totalitarianism) presents a detailed historical study of post-WWII psychoanalysis in Europe and the US, and its wider political context. The book provides us with several paradigmatic case studies in which 'the world kept coming back of its own accord, pressuring all the players in the unfolding controversies to engage in moral-political and not just clinical reasoning, no matter which side of which issue they found themselves on'

\footnotetext{
10 The book was published before Donald Trump was elected to the presidency, which generated some ongoing debates amongst historians on whether or not twentieth-century fascism and authoritarianism is yet to be repeated. See for example Gordon, 2017; Caplan, 2017; Snyder, 2017.
} 
(p. 11). This is, then, another notion of a 'political Freud', one that often - although certainly not always - emerged against the will of its main actors, namely psychoanalysts and theorists themselves.

The first part of the book deals with the de-sexualisation of American psychoanalysis. This process began with 1930s neo-Freudianism, which ironically paved the way for making ego-psychology a 'normative and normalising enterprise' (p. 36), although these two schools were very different in most respects. The common depiction of postwar conservative normativity, especially with regard to sexuality, makes much more sense now when we take into account attempts made by figures like William and Karl Menninger to popularize psychoanalysis by compromising on its emphases on the importance of sexuality, and by gaining new support from the Protestant and Catholic churches in America and millions of believers. Herzog challenges the description of American psychoanalysis as a Jewish science by showing that its popularization was not only achieved by Jewish émigrés but also by local figures who knew how to use psychoanalysis to address some general concerns of those beyond the big urban centres (the Menningers, for instance, worked from Topeka, Kansas). Thus, the book convincingly locates the shaping of postwar American psychoanalysis within a wider cultural history of religion and sexuality, which has been hitherto absent from the historiography.

The history of sexuality appears to have been even further overlooked by recent scholars of psychoanalysis when we read the second chapter about the dark history of - as well as the brave struggle against - homophobia within mainstream psychoanalysis. Rejecting Alfred Kinsey's reports on human sexual behaviour, published first in 1948 and 1953, psychoanalysts were not only the main advocates of heteronormativity, but also stood up against any sort of psychological legitimation for homosexuality. It was only the acceptance of the behaviourist theory of William Masters and Virginia Johnson, as well as the 1970s institutional crisis of American psychoanalysis, that forced psychoanalysts to reconsider their approach to gay patients. The removal of homosexuality from the DSM in 1973 did not leave the psychoanalytic mainstream much room to maintain old homophobic theories, although many of them still did so privately a long time after.

But even that was only the beginning of a different, bitter theoretical and political debate around allowing homosexuals to work as psychoanalysts, which was fiercely resisted by the psychoanalytic establishment. A change came only in the early 1990s, after a long struggle led by a few then-radical new voices such as Robert Stoller, Nancy Chodorow, and Kenneth Lewes. Coming from within psychoanalytic circles, these thinkers started to demand some major revisions to the way that psychoanalysts theorised sexuality in general and homosexuality in particular. For example, by very often mocking the normativity of heterosexuals, Stoller showed the similarities between gays and straight people, arguing that sexuality is far from being all about drives; others like Lewes defended the legitimacy of gays to find their own place in any theory of the drives without being pathologized. As Herzog put it, 'there was and is, apparently, absolutely no necessary correlation between a particular psychoanalytic concept (in this case: drives) and the politics that could, and can, be made of it' (86).

But the most important sections of the book are the second and third sections, entitled 'Nazism legacy', and 'radical Freud', where Herzog turns back to Europe to examine the ways in which European societies came to terms with psychoanalysis after the Second World War and the Holocaust. Chapter 3 reveals yet another dark story from the post-Nazi 
period, where German psychiatrists used Freudian ideas to deny German pensions to Holocaust survivors. Survivors who claimed pensions from the German government had to prove that their ability to support themselves had been damaged by at least 25 percent by Nazi persecution. But German psychiatrists used Freudian discourse to refuse to acknowledge the traumatic life stories of victims, and accused other psychiatrists who did acknowledge them of being naïve. As Israeli psychoanalyst, Hillel Klein put it in 1983, after these trends had already begun to change:

I am ashamed to read the evaluations by my psychiatric colleagues in Germany. They use psychoanalysis to conclude in one case: 'This child was only two years old; how could he experience persecution!,' while in another case maintaining, 'The boy was already thirteen years old and had lived with his parents, so he had experienced the so- called warmth of the family nest.' (102)

These medical opinions fitted perfectly well with the anti-Semitic public discourse of the post-war era: 'Once again, the 'Chosen People' are, each and every one, dancing around the 'golden calf." (97), wrote one letter-writer to Der Spiegel in 1958. The perception that the German reparations were part of wider conspiracy of 'world Jewry' was a major element in the wider atmosphere that helped psychiatrists to deny victims' suffering.

Although there were some 'sympathizers' with victims among these German psychiatrists, it was only in the 1960s and 1970s, when American psychoanalysts such as William Niederland and Kurt R. Eissler began to challenge German psychiatry on this issue, that public and medical opinions shifted towards giving victims the medical acknowledgement they demanded. However, it is not by chance that the 'Americanization' of the debate took place at the same time as American soldiers started to return from Vietnam, and had to face their own struggle with the government for their traumatic experience to be acknowledged by the psychiatric establishment. Indeed, Herzog shows how the highly influential discourse of trauma that emerged in the 1980s - including the creation of the concept of PTSD in 1980 - was the outcome of a direct and indirect 'coalition' between Holocaust survivors in both sides of the Atlantic, post-traumatic Vietnam veterans, and psychiatrists of both groups.

Still in Germany, the following chapter tells the story of the rehabilitation of psychoanalysis in West Germany from the 1950s to the 1990s. It was mainly the concept of 'aggression' (and in that context also the 'death drive') that psychoanalysts and other commentators felt urgently needed explanation. The work of Alexander and Margarete Mitscherlich obviously stands at the centre of this story, but Herzog explores several other, lesser-known debates that influenced and shaped the Mitscherlichs' understanding of the psycho-social condition of Germany after the War. ${ }^{11}$ These debates focused largely on the 'right' reading of the 'real' Freud, and included commentators as different as the egopsychology-influenced zoologist, ethologist, and ornithologist, Konrad Lorenz (who was criticized for his specific understanding of 'aggression' as an inevitable part of human nature, and therefore for somehow exonerating Germany from the crimes of Nazism) - and the Freudian-Marxist philosopher and icon of the New Left, Herbert Marcuse. These highly

${ }^{11}$ On the Mitscherlichs see also ffytche 2017. 
politicised versions of a 'political Freud' also set the terms for the emergence in the 1980s of a German 'object-relations' movement with - again - politicised readings of Klein and Kohut.

The last section of the book focuses on the radicalization of Freud on the Left, achieved, ironically, by some of his main critics, for example the psychoanalyst Felix Guattari and the philosopher Gilles Deleuze in France, on whom the fifth chapter focuses. It is mainly the figure of Guattari, who was considered for many decades - together with other post-structuralists such as his colleague Deleuze, and of course Michel Foucault - to be one of the major critics of Freud, that Herzog wishes to rehabilitate. Deleuze and Guattari's most famous book, Anti-Oedipus (1972), became almost a cult-classic for a whole generation of post-1968 radical leftists, and is still regarded as an anti-Freudian philosophical manifesto. However, Herzog argues that 'Anti-Oedipus needs to be understood also as a psychoanalytic text, not just an attack on psychoanalysis' (156). Indeed, while this book stages an intervention in the Freudian legacy, it also intervenes in the work of other psychoanalytic thinkers such as Lacan, Klein, Reich, and Fanon. It is a philosophical work but also a political call 'against all forms of fascism', to use Foucault's words in his preface to the English translation of the book. As such it contains a radical critique of the Oedipal model of 'daddy-mommy-me', which Deleuze and Guattari saw as too hermetic and misleading an explanation of the social field. As they put it: 'Families are filled with gaps and transected by breaks that are not familial: the Commune, the Dreyfus Affair, religion and atheism, the Spanish Civil War, the rise of fascism, Stalinism, the Vietnam war, May '68 - all these things form complexes of the unconscious, more effective than everlasting Oedipus' (168-9). They suggested a different reading of the unconscious in the social sphere, but by doing so they presented yet another 'political Freud'. Herzog writes:

[Anti-Oedipus] was as much a work of psychoanalysis as Viennese émigré to New York Ernst Kris's conceptualization of danger as an "invigorant" (whether emanating from antisemitic thugs on the street or the encounter with the German Luftwaffe during the evacuation from Dunkirk), or Berlin émigré to Los Angeles Ernst Simmel's theorizations of antisemitism (1946), or British analyst Donald Winnicott's essay on the Berlin Wall (1969), or German analysts Alexander and Margarete Mitscherlich's The Inability to Mourn (1975 [1967]), or Cyprus- born Turkish Muslim American Vamik Volkan's dozens of writings on interethnic conflict worldwide from the 1970s to the present, or the Czech- born New York analyst Martin Bergmann's Generations of the Holocaust (1982) or his "Psychoanalytical Reflections on September, 2001" (2004).Or, for that matter, as Sigmund Freud's Civilization and its Discontents (1930).

In the last chapter of the text, Herzog offers a detailed historical account of postwar continental 'ethnopsychoanalysis' to the English reader for the first time, and in particular the work of the Swiss-based psychoanalysts and anthropologists Paul Parin, Goldy-ParinMatthey, and Fritz Morgenthaler. The question of whether psychoanalysis can be applied in non-Western societies goes back to the debate of Bronislaw Malinowski with the Freudian community on whether or not Oedipus is a valid category in so-called 'primitive' matriarchal societies. While Malinowski was a great admirer of Freud (contrary to the common perception that he was not) he still rejected the idea that the Oedipal model is 
universal. Less skeptical was the Hungarian psychoanalyst and anthropologist Geza Roheim, who attempted to show the universality of the Oedipal structure precisely in societies in Central Australia, such as the one in which Malinowski had claimed the Oedipus complex did not exist. The Parins and Morgenthaler followed Roheim's approach to the universal core of the Oedipal conflict, but took it in a very different direction by being the first ethnographers to conduct psychoanalytic treatment as part of their work in Mali with 'informants-analysands':

They had approached potential informants with a simple overture: "We would like to get to know [the Dogon] and understand how they think and feel." The chief in the village they chose as their home base (Sanga), a man named Ogobara, had volunteered himself spontaneously as the first analysand; soon the news got around that these were "tourists of a special kind" - they did not want to observe any traditional rites like mask dances, but rather wanted to get to know the locals "with their ears." (195)

For the locals, this was also a new anthropological practice - ethnographers who wished to know the people 'by their ears'. But as was true of earlier cases of ethnopsychoanalysis, this experience mainly facilitated the researchers' critique of their own Western society, as well as of their own clinical profession. Analysing informants was a mutual and inter-subjective experience, where the analyst and the analysand are much more equal (indeed, when it came to questions of money, these analysands were paid as informants). This experience helped the Parins and Morgenthaler promote, on their return to Europe, more reciprocal and less hierarchical approaches in the analytical relationships. But they also used this experience for a political critique of European colonialism, capitalism, and the Western tendency to pathologize sexuality. ${ }^{12}$ By the 1970 s and 1980 s they became well-known figures in European New Left circles, and psychoanalysis was part and parcel of their political project. As Paul Parin put it in 1989: 'Psychoanalysis is not possible without an attack on the status quo; the critique of society is intrinsic to it' (213). This was the belief of an entire generation of radical Freudians.

Herzog's narrative is different from most recent historiography for several reasons. First, she starts her story in America and goes back to Europe rather than the better-known story of the exodus of Jewish psychoanalysts from the continent to America in the interwar years. It is also different from most current historical narratives as, in her story, psychoanalysis does not begin its process of slow death in the 1970s when its institutional influence was in decline in American psychiatry; rather, she shows how this was a period of different clinical and political forms of psychoanalytic influence all over the world

12 As Dogon village chief said: 'The whites think too much, and then they do a lot of things; and the more they do, the more they think. And then they earn a lot of money, and when they have a lot of money, they are worried that the money might get lost. Then they think even more and make more money and they never have enough money. Then they're not settled any longer. That's why they're not happy' (Herzog, 196) 
(including the US), and especially in Europe where the discipline was born. ${ }^{13}$ Finally, Herzog provides us with a much-needed detailed history of the Freudian Left - this way of thinking mistakenly perceived by many scholars to have remained undeveloped since the Frankfurt School on the one hand, and not to have survived the post-structuralist critique on the other.

But many of the forgotten heroes and heroines of Herzog were not only Freudian leftists, or even 'political Freudians', but simply very brave observers, who used psychoanalysis to look at things other people wished to forget. As Israeli-German psychoanalyst Sammy Speir wrote in 1987: 'gradually it became clear to me, that behind my fear, and the fear of colleagues and patients, of asking questions of the psychoanalyst, of psychoanalysis, was not the fear of opening the door to the parents' bedroom, and being confronted by the 'primal scene,' but rather, more likely, the fear of opening the door to the gas chambers' (216).

\section{Conclusion}

In 1981, Jacques Derrida gave his lecture on ' Geopsychoanalysis: "... and the rest of the world"', in which he fiercely criticized the International Psychoanalytic Association (IPA) for its refusal to condemn political violence and torture in Argentina in the late 1970s. ${ }^{14}$ I would like to conclude with a lengthy quotation from this text in which Derrida describes the very complex relationship - if one can use such a word in this context between psychoanalysis and violence:

I am not thinking only of the most spectacular ways in which psychoanalytical authorities compromise with political or police authorities, nor, inversely, of the most terrifying forms of persecution of psychoanalysts and their patients; all such instances follow well known and readily identifiable patterns in the face of which positions may be taken up that are perfectly clear and equally valid for any professional, and in a general way for any citizen. For there are also more invisible abuses, ones more difficult to detectwhether in Europe or beyond its borders - and perhaps in some sense newer. Psychoanalysis may serve as a conduit for these new forms of violence; alternatively, it may constitute an irreplaceable means for deciphering them, and hence a prerequisite of their denunciation in specific terms-a necessary precondition, then, of a struggle and a transformation (ibid: 211).

Derrida draws a crossroads for the two different ways in which psychoanalysis can operate - for and against political violence. These two alternative operations can be found all over the history of the 'political Freud', which has been re-written in the last few years.

\footnotetext{
13 Herzog writes: 'On the contrary, what was really going on was that the geographical and generational loci of creativity and influence were shifting'. The end of institutional dominance of psychoanalysis in American psychiatry was the beginning of a 'second "golden age", this one within Western and Central Europe, and [...] also in Latin America' (7).

14 They did eventually publish a very general statement without referring specifically to Argentina, as they asked to do: "The International Psycho-Analytical Association wishes to express its opposition to the use of psychiatric or psychotherapeutic methods to deprive individuals of their legitimate freedom; to an individual's receiving psychiatric or psychotherapeutic treatment based on political considerations; to the interference with professional confidentiality for political purposes. The IPA also condemns the violation of human rights of citizens in general, of scientists and of our colleagues in particular." (Derrida, 1991:209)
} 
However, Derrida defined himself as a 'friend of psychoanalysis' (Derrida and Roudinesco, 2004), and therefore refused to remain silent - not only in the face of such violence but also the failure of persons and institutions from within psychoanalytic circles to speak up. This was an attempt to save psychoanalysis from itself and, as such, an act of friendship. We should not forget, however, that since the 1970s, psychoanalysis and other related psychodynamic methods are under constant attack, not only by critics from the 'psy-profession' but also by the neo-liberal post-welfare state, one of the major goals of which is to replace all forms of psychodynamic psychotherapy with Cognitive Behavioral Therapy (CBT) and pharmaceutical solutions. Derrida argues that human beings cannot be non-political and so psychoanalysis must not be non-political. But it is precisely this political potential - indeed, the potential to become a 'political Freud' - that made and still makes psychoanalysis a target for neo-liberal policy makers, economists, ideologues and the industries behind them. 'Political Freud' has always been and still is a frightening vision for many people and worldviews. Yet it is also a source of hope to many others who understand psychoanalysis, as Derrida did, as almost 'a necessary precondition..., of a struggle and a transformation' (Derrida, 1999:211) . The debate surrounding the 'political Freud' still goes on.

\section{Bibliography}

Bertoldi, Andreas (1998) Oedipus in (South) Africa?: Psychoanalysis and the politics of difference. American Imago 55: 101-134.

Burnham, John C. (2006) The "New Freud Studies": A historiographical shift. Journal of the Historical Society 6: 213-233.

Brickman, Celia (2003) Aboriginal populations in the mind: race and primitivity in psychoanalysis. Chichester: Columbia University Press.

Caplan, Jane (2017) Donald Trump: Between election and inauguration. History Workshop Journal 83: 3-9.

Dagfal, Alejandro (2012) Psychoanalysis in Argentina under Peronism and Anti-Peronism (1943-1963). In Damousi, Joy and Mariano Ben Plotkin (Eds.) (2012) Psychoanalysis and politics: histories of psychoanalysis under conditions of restricted political freedom. New York: Oxford University Press.

Damousi, Joy and Mariano Ben Plotkin (Eds.) (2012) Psychoanalysis and politics: histories of psychoanalysis under conditions of restricted political freedom. New York: Oxford University Press.

Derrida, Jacques (1991) Geopsychoanalysis: "... and the rest of the world". American Imago 48:199-231. 
El Shakry, Omnia (2014) The Arabic Freud: Psychoanalysis and Islam in Modern Egypt. Princeton, NJ: Princeton University Press.

ffytche, Matt (2017) Psychoanalytic sociology and the traumas of history: Alexander Mitscherlich between the disciplines. History of the Human Sciences Vol 30: 3-29

Forrester, John, and Laura Cameron (2017) Freud in Cambridge. Cambridge: Cambridge University Press.

Freud, S. (1914) On the History of the Psycho-Analytic Movement. The Standard Edition of the Complete Psychological Works of Sigmund Freud, Volume XIV. London: The Hogarth Press and the Institute of Psycho-analysis.

Freud, Sigmund (1925) An Autobiographical Study. The Standard Edition of the Complete Psychological Works of Sigmund Freud, Volume XX. London: The Hogarth Press and the Institute of Psycho-analysis.

Khanna, Ranjana (2003) Dark continents: psychoanalysis and colonialism. Durham: Duke University Press.

Leys, Ruth (2011) The Turn to Affect: A Critique. Critical Inquiry 37: 434-472.

Liebscher, Martin (2017) German émigré psychologists in Tel Aviv (1934-58): Max M. Stern and Margarete Braband-Isaac in conflict with Erich Neumann. History of the Human Sciences 30: 54-68.

Gay, Peter (1988) Freud : a life for our time. London : W.W. Norton.

Gay, Peter (1987) A Godless Jew: Freud, atheism, and the making of psychoanalysis. New Haven: Yale University Press.

Gilman, Sander L. (1993) Freud, race, and gender. Princeton: Princeton University Press.

Gordon, Lewis, R. (2015) What Fanon said: a philosophical introduction to his life and thought. London: Hurst \& Company.

Gordon, Peter E. (2017) The authoritarian personality revisited: reading Adorno in the age of Trump. boundary 2 44: 31-56

Guenther, Katja (2015) Localization and Its discontents: a genealogy of psychoanalysis and the neuro disciplines. Chicago: University of Chicago Press.

Hall, Catherine and Daniel Pick (2017) Thinking About Denial. History Workshop Journal, Volume 84, 1 October 2017, Pages 1-23, 
Jones, Ernest (1953-57). Sigmund Freud: life and work Vol. 1-3. London: Hogarth Press.

Mayer, Andreas (2017) Why Does Psychoanalysis Matter to History and Philosophy of Science? On the Ramifications of Forrester's Axiom. Psychoanalysis and History 19: 151-166

Mayer, Andreas (2013) Sites of the unconscious: hypnosis and the emergence of the psychoanalytic setting. Chicago: University of Chicago Press.

Rieff, Philip (1959) Freud: the mind of the moralist. New York: Doubleday.

Robcis, Camille (2013) The Law of Kinship: Anthropology, Psychoanalysis, and the Family in Twentieth-Century France. Ithaca: Cornell University Press.

Rolnik, Eran J. (2012) Freud in Zion: Psychoanalysis and the making of modern Jewish identity. London: Karnac.

Rose, Nikolas (1998) Inventing our selves: psychology, power, and personhood. Cambridge: Cambridge University Press.

Ross, Dorothy (2012) Freud and the vicissitudes of modernism in the United States, 19401980. In John Burnham (ed.), After Freud left: New reflections on a century of psychoanalysis in America. Chicago: Chicago University Press.

Roudinesco Élisabeth (2016) Freud: In His Time and Ours. Cambridge, MA: Harvard University Press.

Russo, Jane A. (2012) The social diffusion of psychoanalysis during the Brazilian military regime: psychological awareness in an age of political repression. In Joy Damousi \& Mariano Ben Plotkin (eds.), Psychoanalysis and politics: Histories of psychoanalysis under conditions of restricted political freedom. New York: Oxford University Press.

Said, Edward W. (2004) Freud and the non-European. London : Verso.

Schorske, Carl E. (1973) Politics and patricide in Freud's Interpretation of Dreams, The American Historical Review 78: 328-347

Shapira, Michal (2013) The war inside: psychoanalysis, total war and the making of the democratic self in postwar Britain. Cambridge: Cambridge University Press.

Slavet, Eliza (2009) Racial Fever: Freud and the Jewish question. New York: Fordham University Press.

Snyder, Timothy (2017) Trump is ushering in a dark new conservatism. The Guardian, 15 July 2017. 
Whitebook, Joel (2017) Freud An Intellectual Biography. Cambridge: Cambridge University Press.

Yerushalmi, Yosef Hayim (1991) Freud's Moses: Judaism terminable and interminable. New Haven: Yale University Press.

Zaretsky, Eli (2016) American Id: Freud on Trump. HuffPost, 24 May 2017. 